\title{
The Paycheck Blues: Why Extra Work is often Not Worth the Effort for Lower-income Families
}

by

\author{
Alexandre Laurin
}

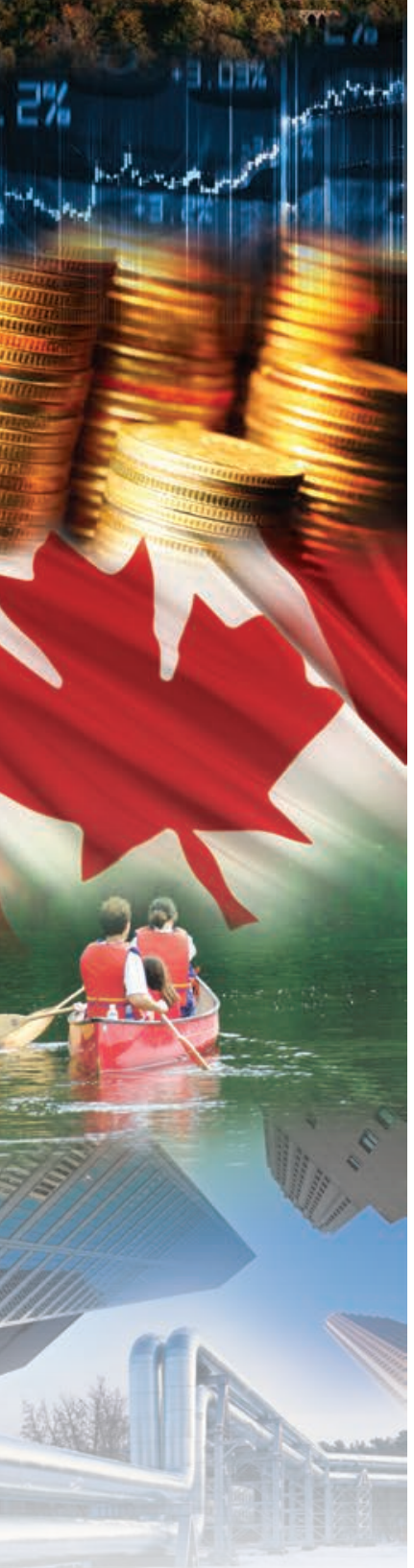

As families earn more income, they owe more tax and they are entitled to lower government payments for fiscal benefit programs. Benefit reductions act like hidden tax rates: they reduce the gains from work. For lower-income families, extra work is often not worth the effort.

- This E-Brief presents various estimates of effective tax rates on personal earnings for families with children. The "marginal" effective tax rate (METR) conveys the loss, through additional taxes and diminished benefits, associated with an extra dollar of earnings. For a working parent, it represents the financial penalty that must be paid for working extra hours.

- The "participation" tax rate (PTR) is the cumulative effect of all taxes, fiscal contributions, payroll deductions and loss of fiscal benefits on the entire prospective earnings from work. For a stay-at-home parent, it represents the financial penalty that must be paid out of the total income derived from getting a job.

- Because benefit programs pile up at the lower end of the income scale, low-income families' METRs generally have been higher than those of higher-income families. In some cases, the lower-earning parent in a dual-earner family with three children might lose more than 70 cents of an extra dollar of earnings, and an unemployed parent more than 65 percent of a prospective salary for taking on a job.

- Federal and provincial policymakers should (i) avoid very high effective rates by better integrating new benefit programs. (ii) Monitor the effectiveness of Quebec's Tax Shield. Since 2016, the new Quebec tax shield has been partly compensating workers for the loss of the work premium and the tax credit for childcare expenses - but only in the first year after they take on more work. (iii) Introduce a refundable credit at the federal level for childcare costs, with very generous rates for lower-earning families.

The income that Canadian families report on their tax returns affects their finances in two ways: the more they make, the more tax they owe, but also the less they receive in fiscal benefits. Fiscal benefits are government redistribution tools. The largest are old age payments to seniors and

The author thanks Daniel Schwanen, Sky Schapiro and anonymous reviewers for comments on an earlier draft. The author retains responsibility for any errors and the views expressed. 
benefits to families with children. Benefits for children play an important role in reducing child poverty by increasing the income of low-income families. For example, in 2019 an Alberta family of four earning $\$ 30,000$ will receive a Canada Child Benefit (CCB) of about $\$ 13,278$ (the maximum amount) and an Alberta Child Benefit of $\$ 1,380$. Fiscal benefits can also mitigate the regressive incidence of consumption taxes (such as the GST tax credit) or other features of the tax system that are considered to favour those with higher incomes disproportionately.

Governments, however, must balance redistributive objectives with the effects these fiscal benefits have on the public purse. Achieving balance requires targeting fiscal benefits to certain income ranges and circumstances. As families earn more taxable income, benefit entitlements are reduced (or "clawed back") at various phaseout rates, which reduces their overall cost and ensures they remain targeted at the intended families. Benefit reductions, however, act like hidden tax rates: they reduce the effective gain from working to earn additional income. To determine the tax system's full effect on the family's financial gain from work, one must take into account the combined effect of both taxes paid and fiscal benefits reduced.

This E-Brief presents various estimates of effective tax rates on personal earnings for families with children. ${ }^{1}$ "Effective" tax rates are computed by adding the amount of lost fiscal benefits to income taxes and payroll contributions paid, divided by gross earnings. ${ }^{2}$ These effective rates play a key role in the work decisions of families by reducing the monetary reward of income they earn. The "marginal" effective tax rate (METR) conveys the loss, through additional taxes and diminished benefits, associated with an extra dollar of earnings. For a working parent, it represents the financial penalty that must be paid from any small addition to income. The "participation" tax rate (PTR) is the cumulative effect of all taxes, fiscal contributions, payroll deductions and loss of fiscal benefits on the entire prospective earnings from work. For a stay-at-home parent, it represents the financial penalty that must be paid out of the total income derived from entering paid employment. Box 1 tells the tale of two illustrative families to present the mechanics behind the METR and PTR calculations.

Because benefit programs pile up at the lower end of the income scale, low-income families' METRs generally have been higher than those of higher-income families. In some cases, the lower-earning parent in a dual-earner family with three children might lose more than 70 cents of an extra dollar of earnings, and an unemployed parent more than 65 percent of a prospective salary for taking on a job. Nationally, 16 percent of working loneparents or the lower-earning parents in dual-income families face a METR above 50 percent, and 12 percent of stay-at-home parents face a PTR above 50 percent. And these proportions have risen substantially since the mid1980s and early 1990s, when very few families faced a METR or PTR greater than 50 percent.

1 Tax rate estimates in this E-brief have been computed using Statistics Canada's tax and fiscal benefit microsimulation tool, the Social Policy Simulation Database and Model (SPSD/M), v. 27.0.1, which provides a high level of detail. Responsibility for all the results presented and their interpretation lies with the author.

2 In other words, effective tax rates comprise statutory income tax (federal and provincial), payroll and other contribution rates, plus the effect of taxback or phaseout rates for each benefit program the household is eligible to receive. The effective tax rates computed here do not take into account social assistance and other income-tested government assistance programs delivered outside the tax system. Adding these programs would worsen work disincentives at very low income levels. On the other hand, payroll contributions to social security programs - for example, Quebec's parental insurance plan, employment insurance and the Canada Pension Plan - included in the tax computations might match expected eventual direct benefits, possibly reducing their effect on work incentives. 


\section{Box 1: Illustrative Calculations of Family METRs and PTRs}

Imagine two families of four, each with two young children. Both families reside in Alberta. For illustrative purposes, each family earns a relatively low income, which means that they are eligible for income-tested benefits.

In Family A, each parent initially earns $\$ 30,000$, and one parent considers earning an additional $\$ 500$. This family serves to illustrate the METR calculation on the additional $\$ 500$. In family $B$, one parent earns $\$ 30,000$ and the other stays at home to care for the children. The stay-at-home parent, however, is considering taking on a job also earning $\$ 30,000$ per year. This family serves to illustrate the PTR calculation on the entire potential $\$ 30,000$.

\section{Family A: The METR}

Each parent earns $\$ 30,000$, for a total family income of $\$ 60,000$. Collectively, they pay $\$ 8,141$ in combined federal income taxes and contributions (employment insurance [EI] and Canada Pension Plan [CPP]) as well as $\$ 1,771$ in Alberta taxes and contributions, for total payments of $\$ 9,912$. They are also entitled to receive a CCB of about $\$ 9,386$ and \$1,245 in provincial benefits (the Alberta Family Employment Tax Credit and the Climate-Change Rebate). Total benefits received minus taxes and contributions paid yields an initial family disposable income of $\$ 60,719$. One parent then considers working overtime for one month to earn an extra $\$ 500$. As a result, family benefits would decrease by $\$ 88$, while federal and provincial taxes and contributions would increase by $\$ 150$; the family's disposable income would increase by $\$ 262(\$ 500-\$ 88-\$ 150)$, rather than the full $\$ 500$.

The METR would be $(\$ 88+\$ 150) / \$ 500=48$ percent.

\section{Family B: The PTR}

In this family, one parent earns $\$ 30,000$ and the other stays at home, for a total family income of $\$ 30,000$. The earning parent pays $\$ 2,262$ in federal income taxes and contributions (EI and CPP), but no Alberta income tax, for total payments of $\$ 2,262$. The family is also entitled to receive a CCB of $\$ 13,278$, a GST tax credit of about $\$ 884$, a Canada Workers Benefit of $\$ 783$, and $\$ 3,299$ in provincial benefits (the Alberta Child Benefit, the Alberta Family Employment Tax Credit and the Climate-Change Rebate). Total benefits received minus taxes and contributions paid yields an initial family disposable income of $\$ 45,982$. The stay-at-home parent then considers taking on employment that would earn $\$ 30,000$. The family's disposable income would increase by $\$ 14,737$, rather than the full $\$ 30,000$, to reach $\$ 60,719$ - reflecting the loss of federal benefits $(\$ 5,559)$, the loss of provincial benefits $(\$ 2,054)$ and the rise of federal and provincial taxes and contributions $(\$ 7,650)$, including the effect of the loss of the spousal credit for the family.

The PTR would be $(\$ 5,559+\$ 2,054+\$ 7,650) / \$ 30,000=51$ percent.

Caution, however, is warranted with regard to using METRs as a metric for financial welfare. High METRs at low incomes generally arise when tax filers receive more generous income support from government, which improves their individual well-being. Having a high METR, therefore, does not necessarily imply that the tax system overall is being unfair to you. The main reason for studying METRs and PT'Rs is their effect on individuals' incentives to earn income, and thus on the incentives to improve their well-being through paid employment. 
Many studies have found a statistical relationship between family work decisions and high marginal and participation tax rates - particularly, a negative effect on work incentives for mothers. ${ }^{3}$ As well, women and mothers, most often the secondary earner and lower-skilled worker in families, are much more responsive to wage and tax-rate variations. These findings mean that a high METR or PTR for a child-caring spouse is likely to affect the incentive to work longer hours, to seek part-time work or to re-enter the workforce. The result is that people are working fewer paid hours than they might otherwise choose.

Because taxes and benefit programs can interact to create extraordinarily high effective tax rates, governments need to be mindful not to discourage work, especially among mothers and secondary earners in a family. This is especially true of families with children eligible for generous child-related fiscal benefits. A rough estimate of the fiscal efficiency cost - that is, the lower tax revenues and higher fiscal benefits that would result from lower employment than would otherwise occur - of income-testing the CCB yields about $\$ 1.9$ billion for 2019, or 8 percent of the total CCB fiscal cost.

Finally, other non-tax family costs, such as paid childcare, also greatly influence work decisions. In particular, the subsidization of childcare expenses has increased parental (primarily maternal) workforce participation. Because most countries offer some tax recognition or subsidization of such expenses, the work incentive indicators employed by the Organisation for Economic Co-operation and Development (OECD) include a PTR measure that accounts for the net cost of childcare (OECD 2019). Adding median paid childcare expenses yields participation tax rates generally ranging from 50 percent to more than 80 percent nationally.

\section{METRs for Parents of Young Children}

Consider a hypothetical two-parent family with young children. ${ }^{4}$ Both parents already work and earn income, but one parent is considering whether to work more to earn extra income. One factor to consider in this decision is how much of the extra income the family would keep after deducting income taxes and the family's reduced government fiscal benefits. In some income ranges and family situations, the family would lose more than half of each extra dollar of earnings - that is, the family's METR would be greater than 50 percent.

Five main factors determine the METR and how much the family would lose in taxes and benefits: the province of residence, the amount of income involved, the number of children, the number of earners in the family, and how earnings are split among the earners. For illustrative simplicity, let us assume that, in dual-earner families, each earner contributes half of the family income.

3 For reviews of the literature on the relationship between wage earnings, taxation and employment, see Bargain, Orsini, and Peichl (2013); Bocconi University (2011); Fortin and Lacroix (2002); and Meghir and Phillips (2010). There is a wide range of empirical results, which vary by subgroups studied, margin of response (participation versus additional work) and empirical methods. Ohanian, Raffo, and Rogerson (2007) find a very strong statistical link between hours of work and labour taxes across member countries of the Organisation for Economic Co-operation and Development. Causa (2009) finds a significant tax-induced labour-supply response on the part of women, but not of men.

4 Scenario-based METRs and PTRs have been computed assuming children are younger than age 6. METRs and PTRs for families with children between the ages of 6 to 17 will be very similar - often identical. For example, CCB base amounts differ by the ages of children (older children receive about 15 percent less), but not the reduction rates and income thresholds. Therefore, the effect of the CCB on METRs and PTRs will be the same even for older children, but it will be felt up to a lower level of family income. 
At very low family employment income levels - from about $\$ 3,000$ to $\$ 10,000$ - the federal Canada Workers Benefit (CWB, renamed in 2019 from the Working Income Tax Benefit) rewards workers for taking on more work, resulting in negative METRs. ${ }^{5}$ Past the $\$ 17,000$ mark, however, as the CWB and most other federal and provincial refundable credit and income-tested benefits are successively (and sometimes simultaneously) reduced with each extra dollar of earnings, the METR climbs rapidly to levels approaching or surpassing 50 percent for families with at least two children, and stays at around this level from about $\$ 30,000$ to $\$ 55,000$ of family income (Figure 1). METRs are generally slightly higher for single-parent families, and the gap grows larger at higher income levels, due to the individual tax unit and the progressivity of the tax system.

METRs generally peak at family incomes around the $\$ 50,000$ mark. As Figure 1 shows, in Ontario the family METR on extra earned income peaks at 60 percent for two-children, two-parent families, and at 76 percent for lone-parent families. In Quebec, it peaks higher at 72 and 78 percent, respectively. In other provinces, it tends to peak at around 50 to 60 percent. $^{6}$ In short, METRs reach their peak at relatively low levels of family income for two-parent families, and at around average income levels for single-parent families. Past their peak, they drop to the mid-30 percent range, but quickly increase again with income as reductions of income-tested benefits give way to progressively increasing statutory tax rates.

\section{PTRs for the Non-working Second Parent}

It is often difficult for workers to choose the number of hours they work - employment is usually offered on the basis of a set number of expected hours. In many two-parent families with young children, the second potential earner must decide whether to look for work or to remain at home as a caregiver. The higher the PTR - the proportion of total earnings lost to taxes and withdrawn benefits - the lower the incentive to take on employment.

Consider, for example, two hypothetical scenarios in which one of the parents of young children (often, but not necessarily the mother) is currently not employed but contemplating taking on paid work (Table 1 ). How much of this parent's earnings would the family keep after taking into consideration additional taxes paid and benefits reduced? These sums, or the PTR, depend in part on the other parent's income, since fiscal benefit entitlements are set according to family income, as are a few tax credits (such as the spousal credit) and other contributions (such as the Ontario Health Premium).

In the first scenario, the currently unemployed parent is considering taking a job making $\$ 20,000$ a year, while the working spouse is making $\$ 42,000$. In the second scenario, the unemployed parent is considering a job paying $\$ 50,000$ a year, while the working spouse is making $\$ 90,000$. These two scenarios are roughly representative of dual-earner families with young children respectively at the first quartile and at the third quartile of the employment income distribution.

5 The CWB's purpose is to counter the "welfare wall" originating from the loss of social assistance and other welfare benefits as recipients return to work.

6 This ignores abrupt but spurious METR jumps resulting from the Ontario Health Premium and the Newfoundland Temporary Deficit Reduction Levy: by design, the METR jumps, then falls abruptly on very short spans of income. 


\section{Figure 1: Marginal Effective Tax Rates for Typical Lone-Parent and Dual-Earner Families} with Two Children, by Province, 2019
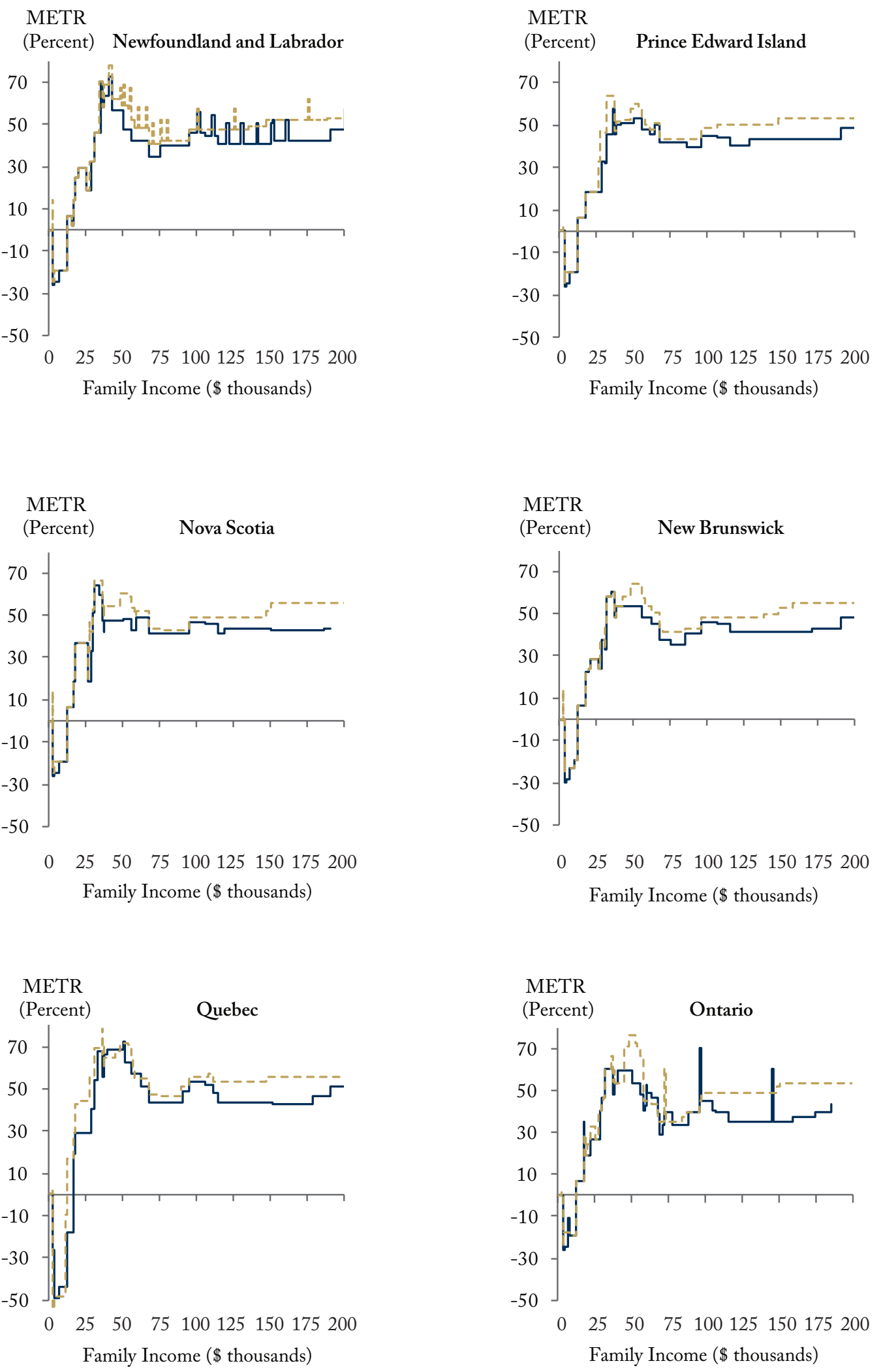


\section{Figure 1: Continued}

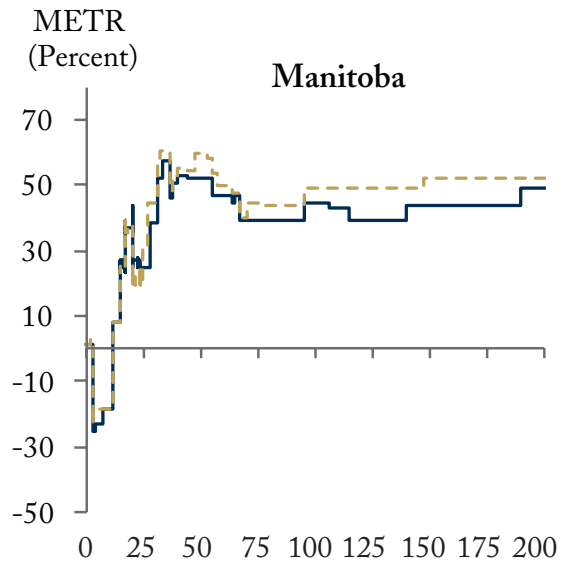

Family Income (\$ thousands)

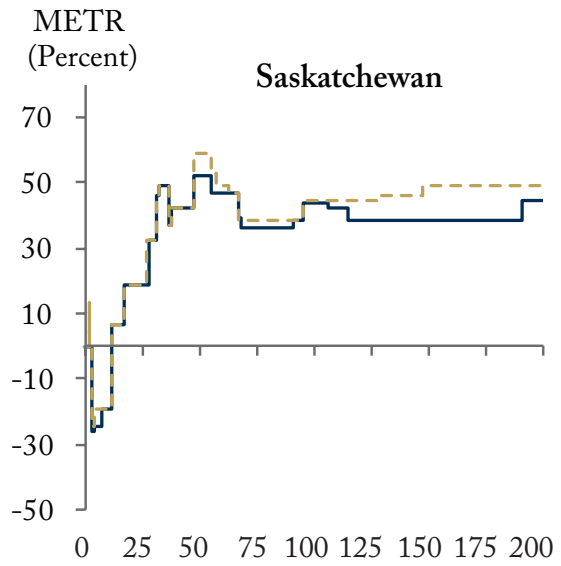

Family Income (\$ thousands)

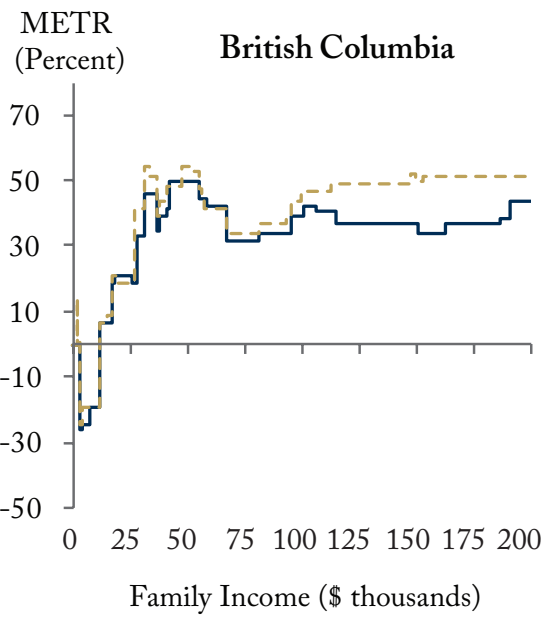

Assumptions: The simulated families consist of a lone parent with two children (dotted line) and two parents with two children (solid line). Both children are under age six. In the case of the two-parent family, each parent earns 50 percent of the family's income. The family's sole income source is employment. The Ontario Health Premium is modelled, but not childcare expenses or British Columbia Medical Services Plan premiums and related premium assistance. The METRs shown here apply to each additional dollar of family income.

Source: Author's calculations using Statistics Canada's SPSD/M, v. 27.01. 


\section{Table 1: Participation Tax Rates for a Stay-at-Home (Second Parent) Contemplating Taking on Paid Work, by Province, 2019}

\begin{tabular}{|c|c|c|c|c|c|c|}
\hline \multirow{3}{*}{ Province } & \multicolumn{3}{|c|}{$\begin{array}{c}\text { First Parent's Income Is } \$ 42,000, \\
\text { Second Parent Expects to Make } \$ 20,000 \\
\text { Number of Children }\end{array}$} & \multicolumn{3}{|c|}{$\begin{array}{c}\text { First Parent's Income Is } \$ 90,000, \\
\text { Second Parent Expects to Make } \$ 50,000 \\
\text { Number of Children }\end{array}$} \\
\hline & 1 & 2 & 3 & 1 & 2 & 3 \\
\hline & \multicolumn{6}{|c|}{$\begin{array}{c}\text { Participation Tax Rate } \\
\text { (percent) }\end{array}$} \\
\hline $\begin{array}{l}\text { Newfoundland \& } \\
\text { Labrador }\end{array}$ & 39 & 47 & 54 & 33 & 35 & 38 \\
\hline Prince Edward Island & 38 & 45 & 51 & 36 & 38 & 41 \\
\hline Nova Scotia & 36 & 43 & 48 & 34 & 36 & 38 \\
\hline New Brunswick & 42 & 49 & 56 & 33 & 36 & 38 \\
\hline Quebec & 53 & 61 & 67 & 37 & 41 & 44 \\
\hline Ontario & 39 & 51 & 56 & 30 & 32 & 35 \\
\hline Manitoba & 42 & 49 & 55 & 34 & 37 & 39 \\
\hline Saskatchewan & 41 & 46 & 49 & 34 & 36 & 38 \\
\hline Alberta & 42 & 50 & 56 & 34 & 36 & 39 \\
\hline British Columbia & 35 & 43 & 50 & 30 & 33 & 37 \\
\hline Canada average & 42 & 52 & 57 & 33 & 35 & 38 \\
\hline
\end{tabular}

As Table 1 shows, in the first scenario, where one parent already earns $\$ 42,000$, the other parent contemplating earning $\$ 20,000$ would face the highest PTR in Quebec (a staggering 67 percent if the family has three children, 61 percent if two children and 53 percent if one child), followed by Ontario ( 56 percent, 51 percent and 39 percent, respectively) and Alberta (56 percent, 50 percent and 42 percent, respectively), mainly due to the phase-out of generous income-tested child-related fiscal benefit programs. On average across Canada, the PTR reaches 57 percent for families with 3 children, 52 percent for families with 2 children, and 42 percent for single-child families. Generally, about half of the PTR value at lower family income thresholds is accounted for by the withdrawal of income-tested government benefits.

The PTR comes down substantially the more the working parent earns, since family income is greater to begin with, and thus family benefits received are lower in the first place or even fully clawed back. For example, in the second scenario, where one parent earns $\$ 90,000$, the family would lose only about 3 to 11 percent in fiscal benefits, on average, of the prospective $\$ 50,000$ the other parent contemplates earning. With taxes and other contributions in the order of 25 percent (British Columbia) to 34 percent (Quebec), the PTR ranges from a low of 30-35 percent in Ontario to a high of 37-44 percent in Quebec. On average, at this higher family income 
Figure 2: Participation Tax Rates Inclusive of Median Childcare Expenses (CCE) for a Stayat-Home (Second Parent) in a Family of Four Contemplating Taking on Paid Work, Quebec, Ontario and the Rest of Canada, 2019

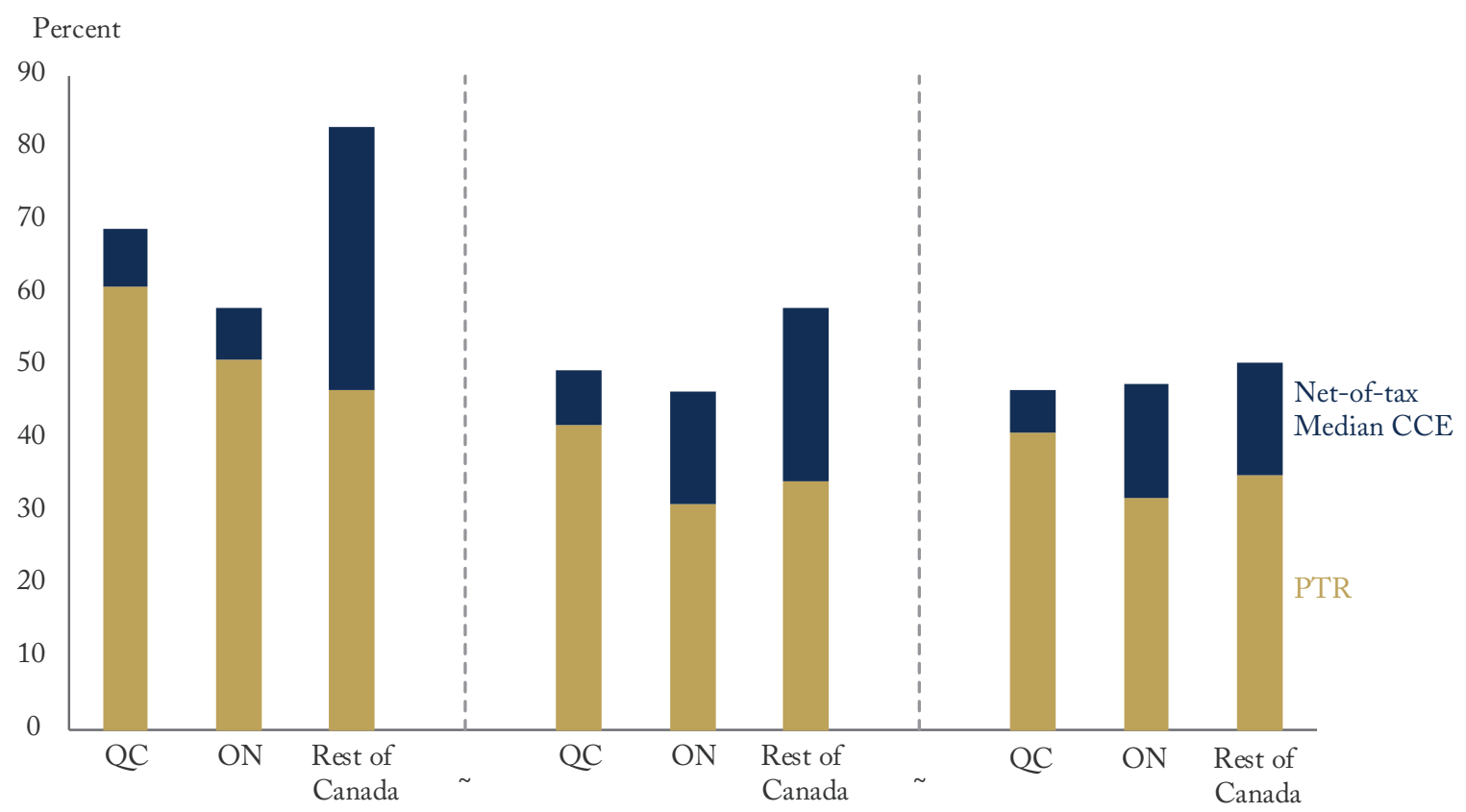

First Parent's Income $=\$ 40,000$

Second Parent Expects to

Make $\$ 22,000$
First Parent's Income $=\$ 66,000$

Second Parent Expects to

Make $\$ 33,000$
First Parent's Income $=\$ 90,000$

Second Parent Expects to

Make $\$ 50,000$

Notes: Includes Ontario Childcare Access and Relief from Expenses tax credit introduced in 2019 Ontario budget. Gross median value of childcare expenses is $\$ 11,374$. Rest-of-Canada average is population weighted.

Source: Author's calculations using Statistics Canada's SPSD/M, v. 27.0.1.

level, the PTR reaches 38 percent for families with three children, 35 percent for families with two children and 33 percent for single-child families.

Taxes, contributions and benefit clawbacks are only one cost of employment for families. For the nonworking parent, taking on employment can mean added expenses to the family budget for transportation, work clothing and meals, for example. It can also mean added childcare expenses (CCE). It is possible to compute PTRs inclusive of after-tax childcare expenses - that is, the net cost of childcare expenses after the fiscal effect of the childcare expense deduction (in addition to the childcare expense credit in Quebec and the newly implemented CARE credit in Ontario).

Figure 2 shows the effect on the PTR of median after-tax childcare expenses claimed by Canadian families with two young children under three income scenarios (the median gross CCE claim is \$11,374). Naturally, PTRs inclusive of net-of-tax childcare expenses are higher than in the base case, especially for lower-income families. Outside Quebec and Ontario, in the scenario in which one parent already earns $\$ 42,000$, the other parent contemplating earning $\$ 20,000$ faces a PTR that rises sharply from less than 50 percent to more than 80 percent on average as a result of net childcare costs. Such a high PTR is likely a significant hindrance to participation in 
work. Quebec provides a generous tax credit for childcare expenses, while, in its 2019 budget, Ontario recently introduced a similar tax credit for childcare expenses, the Ontario Childcare Access and Relief from Expenses (CARE) tax credit. These credits produce relatively lower after-tax childcare costs in the two provinces than in the rest of Canada. At the lower-income level, the new Ontario tax credit, in particular, reduces the PTR from greater than 80 percent to less than 60 percent, the lowest of any province.

\section{The Extent and Evolution of High Effective Rates for Canadian Families}

The scenarios above show the extent to which Canadian families may be exposed to high effective rates. But how typical are they? One way to determine this is to compute detailed METRs and PTRs for a large representative sample of the Canadian population, and generate a frequency distribution. There are currently about 2.3 million two-parent families in Canada with at least one child younger than age 12. Of these, a quarter have a stay-at-home parent; of the 1.7 million others, most lower-earning parents (79 percent) are mothers. In addition, there are about 0.9 million single-parent families with at least one child younger than 12 .

Of all working lone parents and secondary-earning parents (the lower-earning parent in two-parent families) in 2019, 23 percent face a METR below 30 percent. Another 61 percent face a METR between 31 and 50 percent, leaving 16 percent of lone/secondary-earning parents facing a METR higher than 50 percent (Figure 3). The share of Canadian parents facing very high METRs was starkly lower in the 1980s, before the introduction of income-tested refundable child tax credits in the 1990s. Between 1995 and 2019, the share of parents facing a METR higher than 50 percent remained relatively stable, oscillating between 14 and 17 percent.

The share of stay-at-home parents (in two-parent families) facing a PTR greater than 50 percent, on the other hand, increased more gradually from 1995 to 2015. From the mid-1980s to the mid-1990s, very few stay-athome parents faced a PTR in excess of 50 percent; by 2015, the share facing such a high PTR had increased to 13 percent. In 2019, 30 percent face a PTR below 30 percent, while another 58 percent face a PTR between 31 and 50 percent, leaving 12 percent of non-working parents contemplating a relatively very high PTR of more than 50 percent (Figure 4).

\section{Simulating Potential Effects on Work Decisions}

Considering that costs other than taxes - such as childcare, transportation and clothing - might affect the financial decision to work, it seems reasonable to assume that high METRs and PTRs might affect work decisions at the margin. What magnitude of work response could we expect from policies aimed at reducing effective tax rates? This is a very difficult question because estimated paid-work responsiveness to changes in taxes and benefits varies widely in the economic literature. In general, lower-income, less-educated people have a greater tendency to adjust their paid work behaviour through workforce participation decisions, while more-educated workers tend to adjust through the number of hours they work. Older workers nearing retirement are also affected by the tax-and-transfer system (Duclos et al. 2014).

Although there is no real consensus in the literature, in general the evidence points to insignificant work response on the part of primary-earner men to tax changes; if positive, the response level tends to be very low on average (Meghir and Phillips 2010). The literature is more conclusive with respect to secondary earners in a family, especially mothers of young children, and single mothers. This is especially true for the decision about whether to take paid work, which, for married women in particular, is quite sensitive to taxation and fiscal 


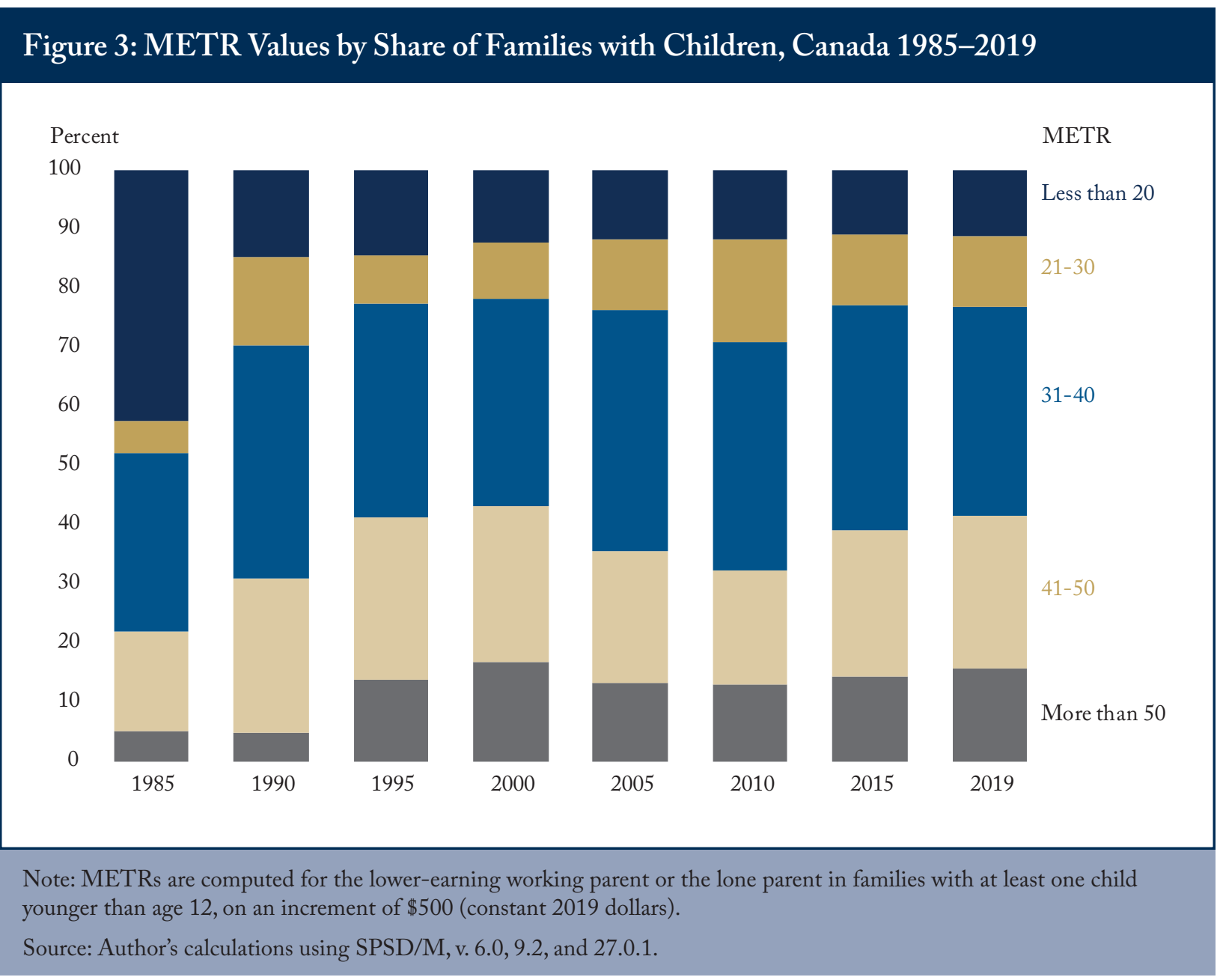

benefits. In general, the effect of taxation on the work decision is stronger for low-skilled women and for those with young children (Causa 2009; Kalyva et al. 2018).

\section{Simulating the Efficiency Cost of the CCB}

The most targeted way to reduce effective tax rates for families with children would be to alter CCB reduction rates. Under the CCB, in 2019, families may receive up to $\$ 6,639$ per child under age 6 and $\$ 5,602$ per child between 6 and 17. Depending on the number of children, these amounts are reduced by 7-23 percent of family income between $\$ 31,120$ and $\$ 67,426$, and by 3.2-9.5 percent of income beyond this threshold. CCB reduction rates are designed to provide greater benefits to lower-income families, but this family income testing contributes to higher family METRs and PTRs, and thus comes with an economic efficiency cost.

It would be practically impossible to reduce CCB clawback rates considerably across the board without producing large benefit redistributions from less well off to more well off families. This is the classic fiscal policy tradeoff of income redistribution versus economic efficiency. However, society also might value redistributive fairness, especially if it leads to lower child poverty, so the economic efficiency costs of such a tradeoff still might be lower than the value society attaches to income redistribution. 


\section{Figure 4: PTR Values by Share of Stay-at-Home Parents, Canada, 1985-2019}

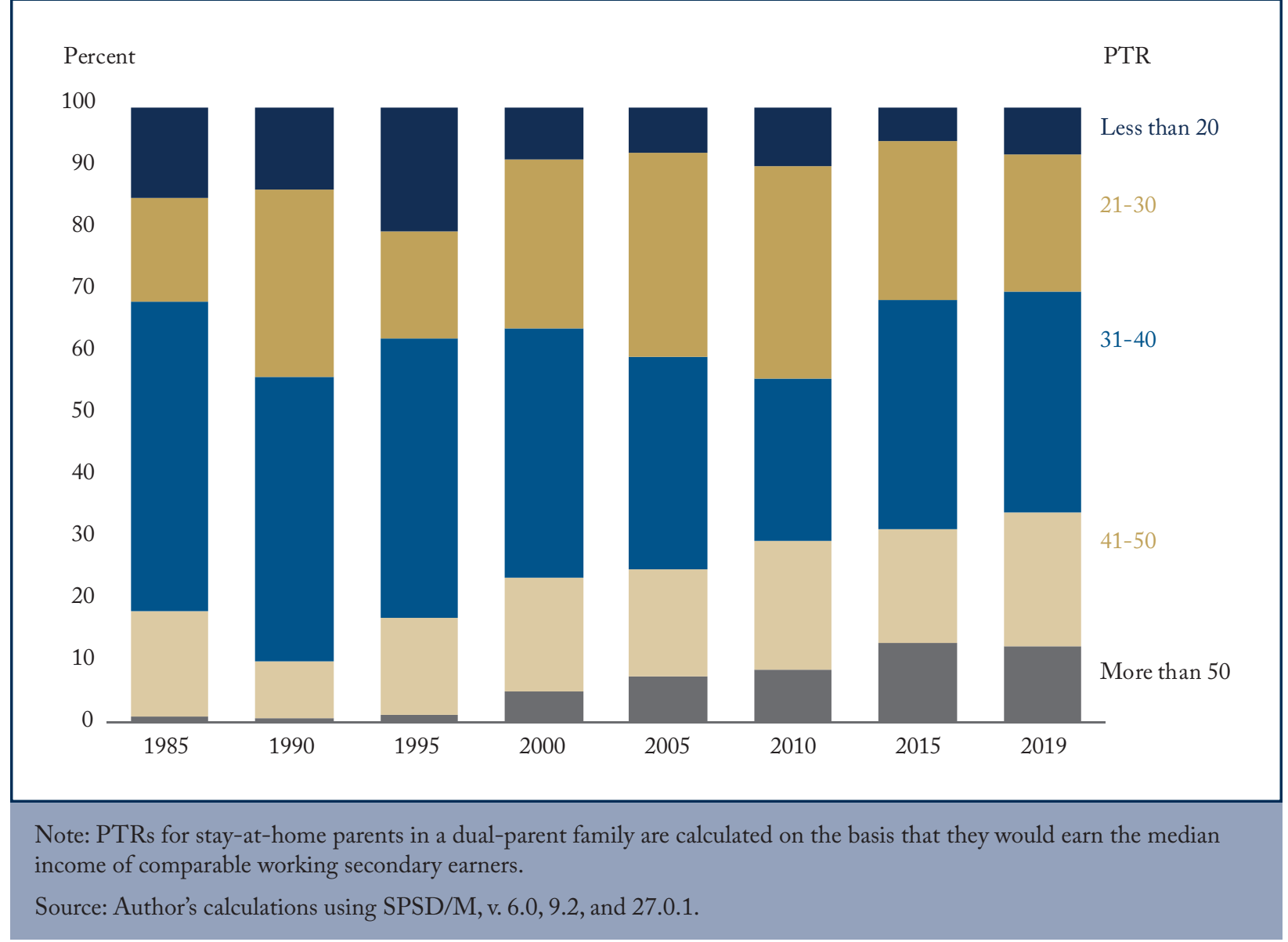

To evaluate the economic efficiency cost of CCB targeting, we can simulate an alternative scenario in which practically all income-tested CCB reductions are eliminated while cost neutrality is maintained - that is, the annual fiscal cost of the CCB would remain at its current $\$ 24$ billion. In this scenario, every family below a $\$ 300,000$ income threshold would receive a flat, unreduced amount ${ }^{7}$ of $\$ 3,714$ per child under age 6 and $\$ 3,134$ per child between 6 and 17 . Since this scenario would practically eliminate all income-tested CCB reductions but leave the program cost intact, the current level of income testing for CCB payments enables lowerincome families to enjoy CCB benefits nearly 80 percent higher than otherwise. But this comes at the cost of higher METRs and PTRs for secondary earners in a family and for lone parents: on average, METRs are higher by five percentage points and PTRs higher by six percentage points.

To simulate potential labour supply effects of higher METRs and PTRs, one can use response rate estimates found in the literature, but these are often evaluated from actual policy reforms in a quasi-experimental

7 CCB amounts would be rapidly reduced to zero over the $\$ 300,000$ threshold at a rate of 50 percent of income. A $\$ 300,000$ threshold was chosen because a) few families earn as much; and b) on distributional equity grounds, most people would object to very high income families receiving fiscal benefits. 
methodological framework, and thus a particular study might not always yield results applicable in a different context. For this reason, hours-of-work and workforce participation response rates for secondary earners can be used that are conservatively in the low- to mid-range of elasticities evaluated in the literature. ${ }^{8}$ I calculate that higher PT'Rs might lead to a 10 percent increase in the number of stay-at-home parents, lowering aggregate employment income by about $\$ 2.0$ billion and federal/provincial net revenues by $\$ 390$ million. In addition, higher METRs might lead secondary earning parents and lone parents to earn about $\$ 1,450$ less on average, which would translate to aggregate employment income that is lower by about $\$ 4.5$ billion and federal/provincial net revenues lower by about $\$ 1.5$ billion. In total, the fiscal efficiency cost of targeting the CCB to lower-income families would approach $\$ 1.9$ billion, or 8 percent of the total fiscal cost of the CCB.

\section{Policy Implications}

\section{Avoid Very High Rates by Better Integrating New Benefit Programs}

Federal and provincial governments should be careful not to pile up income-tested fiscal benefit programs on top of one another, since clawback rates can add up to create very high effective tax rates - sometimes above 50 percent - at lower income levels. Instead, income testing of multiple fiscal benefits requires an integrated approach to reduction rates.

When thinking of new income-tested benefit programs, in particular, policymakers should be conscious of the added economic and fiscal costs associated with income testing and clawback rates - and this added efficiency cost should be balanced against the social benefits of income targeting. In the case of the existing federal CCB, income testing provides higher benefits to low-income families but creates additional costs in terms of inducing lower-paid work: I estimate that the negative effect on labour supply implicitly increases the net revenue cost of the CCB by about 8 percent of its fiscal cost. Many advocates of poverty reduction and redistributive policies would find this efficiency cost of reasonable magnitude.

\section{Monitor the Effectiveness of Quebec's Tax Shield}

Recognizing the work disincentive stemming from high effective tax rates, in 2015 the Quebec Taxation Review Committee, chaired by Luc Godbout of the Université de Sherbrooke, proposed a new initiative known as a "tax shield." Its intent was to offset the loss of income-tested fiscal benefits as families earn additional income. The Quebec government followed through on the recommendation, and since 2016 the new Quebec tax shield has been partly compensating workers for the loss of the work premium and the tax credit for childcare expenses - but only in the first year after they take on more work. On the assumption that work decisions are mostly influenced by short-term financial considerations, the tax-shield approach might enable governments to provide

8 For the participation response to change in participation rates for secondary earners, I used an elasticity of 0.25 , which corresponds to a middle-of-the-range participation elasticity value for female secondary earners found in Bartels and Shupe (2018). Tsounta (2006) finds a similar participation elasticity (0.24) for female Canadians specifically. For the work intensity response to changes in the METR of secondary earners who are currently working, my preferred estimate is from Causa (2009), who studied the hours-of-work response of mothers and fathers with children, conditional on employment, and finds that a one percentage point increase in the METR leads to a 0.8 percent decrease in hours of work (which roughly corresponds to a wage elasticity of 0.4 ). 
relief from high effective tax rates at a low fiscal cost (because relief is only offered for one year after taking on extra work) while maintaining the same level of generosity of targeted fiscal benefits. More than 400,000 Quebec households took advantage of the tax shield in 2017 , for a cost of only $\$ 65$ million. Originally, the credit ceiling was set at $\$ 2,500$ per worker, but it has since been increased to $\$ 4,000$ in successive budgets (CFFP 2019). It will be interesting to monitor the effectiveness of this new measure in Quebec.

\section{Childcare Subsidization}

For most parents, childcare costs are like taxes in that they reduce the financial incentive to work. As shown in Figure 2, childcare costs can raise the PTR significantly for parents of young children, particularly in jurisdictions without extra fiscal subsidization. One interesting avenue for augmenting labour force participation among twoparent families would be to revisit the tax deduction for childcare expenses. In the current system, childcare expenses must be deducted on the tax return of the lower-earning spouse, and claims cannot exceed the lowest of either (a) two-thirds of the spouse's income or (b) a maximum claim per child. As a result, up to one-third of families, mostly among those at lower income levels, cannot deduct their childcare expenses fully because of the two-thirds-of-income limit or, mostly among those at higher income levels, the maximum claim limits (Laurin and Milligan 2017).

Both Quebec (in 1994) and Ontario (in 2019) have introduced a refundable credit for childcare costs on top of the federal tax deduction, resulting in considerably lower PTRs for parents in lower-income families. Laurin and Milligan (2017) have proposed a similar refundable credit at the federal level for childcare costs, with very generous rates for lower-earning families - designed along the lines of the Quebec childcare expenses credit and diminishing up the income scale to higher-earning families, which would still reap some benefit. ${ }^{9}$ This would be a major change for low earners in provinces other than Quebec and Ontario who are limited in their ability to take full advantage of the deduction; with such a credit, these families could get most of their childcare expenses refunded. Because the work decisions of parents, especially mothers, are particularly sensitive to changes in childcare costs, a more generous tax treatment along the lines proposed here likely would encourage many more stay-at-home mothers to join the workforce and remain employed over the long term, alongside increasing government revenues (Laurin and Milligan 2017).

\section{Conclusion}

Federal and provincial policy makers should pay special attention to effective tax rates when considering changes to the tax-and-transfer system. Clearly, geared-to-income fiscal benefit programs provide valuable financial assistance to families with children. However, these benefits can come with high marginal effective tax rates and participation tax rates, especially for those at lower income levels.

9 The proposed refundable credit would be income tested to reduce its fiscal cost, which means that it would somewhat increase the METR on family income. The negative effect on work incentives, however, likely would be more than offset by a significant positive work incentive effect due to a decrease in the PTR inclusive of net childcare expenses. 
Any further expansion of the targeted transfer system - through larger low-income supplements or the creation of new targeted family benefits, for example - should be approached with a broader analysis of the effect on parents' work decisions. Relief measures meant to encourage work participation, such as Quebec's newly created tax shield, should be explored. Greater tax relief for childcare expenses - a key factor in family paid-work decisions - could also be explored. 


\section{References}

Bargain, Olivier, Kristian Orsini, and Andreas Peichl. 2013. "Comparing Labor Supply Elasticities in Europe and the US: New Results.” NEUJOBS Working Paper D 10.6. January.

Bartels, Charlotte, and Cortnie Shupe. 2018. "Drivers of Participation Elasticities across Europe: Gender or Earner Role within the Household?” Disussion Paper 11359. Bonn: IZA Institute of Labor Economics.

Bocconi University. 2011. “The Role and Impact of Labour Taxation Policies.” Milan: Centre for Research on the Public Sector.

Causa, Orsetta. 2009. "The Policy Determinants of Hours Worked across OECD Countries.” OECD Journal: Economic Studies 2009 (1) : 1-39.

CRFFP (Chaire de recherche en fiscalité et en finances publiques). 2019. «Guide des mesures fiscales, année d'imposition 2018. » Cahier de recherche 2019/03. Sherbrooke, QC: Université de Sherbrooke.

Duclos, Jean-Yves, Arnaud Blancquaert, Nicholas-James Clavet, and Steve Marchand. 2014. "La fiscalité québécoise et l'incitation au travail.” Working paper. Quebec City: Commission d'examen sur la fiscalité.

Fortin, Bernard, and Guy Lacroix. 2002. "Assessing the Impact of Tax and Transfer Policies on Labour Supply: A Survey.” Montreal: Centre interuniversitaire de recherche en analyse des organisations. April.

Kalyva, Athena, Savina Princen, Alexander Leodolter, and Caterina Astarita. "Labour Taxation \& Inclusive Growth.” European Economy Discussion Paper 084. Luxembourg: European Union.

Laurin, Alexandre, and Kevin Milligan. 2017. Tax Options for Childcare that Encourage Work, Flexibility, Choice, Fairness, and Quality. Commentary 481. Toronto: C.D. Howe Institute. May.

Meghir, Costas, and David Phillips. 2010. "Labour Supply and Taxes.” In Dimensions of Tax Design: The Mirrlees Review, Institute for Fiscal Studies, 202-74. Oxford: Oxford University Press.

OECD (Organisation for Economic Co-operation and Development). 2019. "The OECD Tax-Benefit Data Portal.” Available online at http://www.oecd.org/els/benefits-and-wages-statistics.htm.

Ohanian, Lee, Andrea Raffo, and Richard Rogerson. 2007. "Work and Taxes: Allocation of Time in OECD Countries.” Federal Reserve Bank of Kansas City Economic Review, Third Quarter.

Tsounta, Evridiki. 2006. "Why Are Women Working So Much More in Canada? An International Perspective.” IMF Working Paper. Washington, DC: International Monetary Fund. April.

This E-Brief is a publication of the C.D. Howe Institute.

Alexandre Laurin is Director of Research at the C.D. Howe Institute.

This E-Brief is available at www.cdhowe.org.

Permission is granted to reprint this text if the content is not altered and proper attribution is provided.

The views expressed here are those of the author. The C.D. Howe Institute does not take corporate positions on policy matters. 